\title{
Surirella prespanensis sp. nov. and Surirella hinziae sp. nov., two new diatom (Bacillariophyceae) species from ancient Lake Prespa (Macedonia/Albania/ Greece)
}

\author{
Aleksandra Cvetкoska ${ }^{1}$, Paul B. Hamilton ${ }^{2} \&$ Zlatko Levkov $^{3}$
}

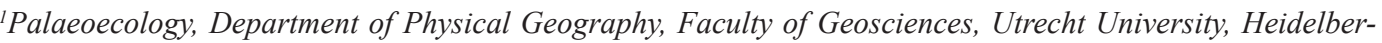 \\ glaan 2 Utrecht, The Netherlands; *Corresponding authore-mail: acvetkoska@yahoo.com \\ ${ }^{2}$ Phycology Section, Research and Collections Division, Canadian Museum of Nature, P.O. Box 3443, Station \\ D, Ottawa, Canada \\ ${ }^{3}$ Institute of Biology, Faculty of Natural Sciences, Arhimedova 3, 1000 Skopje, R. of Macedonia
}

\begin{abstract}
Surirella is a polyphyletic and highly diverse diatom genus with more than 500 species described worldwide. Within a study of its diversity and distribution in the Republic of Macedonia, ancient Lake Prespa has been investigated, as "sister" to Lake Ohrid and part of a unique lake system with extraordinary age, biodiversity and number of endemic species. During the study, two new Surirella species have been identified and their LM and SEM based formal descriptions and differential diagnoses are provided herein. Surirella prespanensis sp. nov. has been observed in the contemporary and the fossil diatom flora of the lake. It can be distinguished from other similar taxa by its valve outline, size, shape of the median ridge and the presence of silica grooves along the raphe. Surirella hinziae sp. nov. is known only from the fossil diatom flora of Lake Prespa and can be recognized by its valve outline, size, shape of the median ridge and the presence of helictoglossa-like processes.
\end{abstract}

Key words: Lake Prespa, diatoms, Surirella prespanensis, Surirella hinziae

\section{INTRODUCTION}

Surirella TURPIN (1828) is among the most taxonomically diverse diatom genera; more than 500 taxa have been described in a range of benthic habitats from diverse aquatic environments worldwide (FOURTANIER \& KocioleK 2011). The most characteristic feature of the genus is the circumferential marginal raphe system, raised or not raised within a keel. In the middle of the XIX century a number of Surirella species, intraspecific varieties and forms were described, however many of the descriptions or illustrations were incomplete or confusing. The most obvious examples of confusion are $S$. biseriata Brébisson, S. bifrons Ehrenderg, $S$. linearis W. Smith, and $S$. robusta Ehrenberg. Some taxonomic problems have been recently addressed by re-examination, typification and/or description of new Surirella taxa, mainly from Отто MülLERS' collection from East Africa (CoCQUYT \& J JHN 2005, 2007; CocQuYT et al. 2008), Gandhs' collection from India (Karthick 2009; Karthick et al. 2012), the Malili lakes in Indonesia (Bramburger et al. 2008) and several localities from North America (VeselÁ et al. 2013;
Veselá \& Potapova 2014). Recent molecular analyses further indicate that Suirella is a polyphyletic genus (Ruck \& Kociolek 2004) and additional studies of the morphological characters, as well as the ecological preferences of individual taxa, are required to resolve phylogenetic relationships within the genus.

Diatom research in Republic of Macedonia has a long history dating back to the first investigations of Fотт $(1933,1935)$. The most comprehensive studies have been conducted on ancient Lake Ohrid (JuRILJ 1948, 1954, 1956a, b; Levkov et al. 2007; Cvetкoska et al. 2012; Levkov \& Williams 2012). In contrast, information from other localities is sparse. More specifically, across the Republic of Macedonia, there is limited information about the genus Surirella. Ancient Lake Prespa was observed to have many tentatively identified Surirella taxa (Levkov et al. 2007). Recent observations have demonstrated the presence of approximately 20 Surirella taxa in Lake Prespa (pers. obs.). Therefore the objective of the current investigation is to examine in detail and circumscribe some of the taxa observed from Lake Prespa.

Ancient Lake Prespa co-existed with its nei- 
ghboring Lake Ohrid for more than $1 \mathrm{Ma}$ (STANKović 1960; Albrecht \& WilKe 2008), and as such, the "sister lake system" is unique in offering an extraordinary opportunity for biodiversity, evolutionary and Quaternary research. Apart from the few taxonomic and diversity studies of the contemporary diatom flora (LEVKOv et al. 2007; LeVkov \& Williams 2012; CVETKOSKA et al. 2014a, b) and the investigations of the fossil diatom flora (Aulacoseira THWAITES, Tertiarius HAKANSSON et KHURSEVICH) from Neogene lacustrine deposits (Ognjanova-Rumenova \& Dumurdzanov 2008; OgnJANOVA-Rumenova \& CRAWFord 2012), no other fossil diatom data have been generated from Lake Prespa. This study complements previous research of CVETKOSKA et al. (2014b) on Lake Prespa and presents the descriptions and differential diagnoses of two Surirella species new to science. Surirella prespanensis sp. nov., is identified from the modern, as well as the fossil diatom flora of Lake Prespa, while the second taxon, $S$. hinziae sp. nov., is a fossil species, probably with a late Pleistocene distribution.

\section{Material AND Methods}

Samples. During an extensive biogeographical and paleoclimate study more than 1000 modern and fossil diatom samples were examined from the Macedonian part of Lake Prespa. Modern samples containing high abundance of Surirella taxa were selected from a collection of samples originating from different field campaigns carried out between 2002 and 2008 at various locations around the lake (Levkov et al. 2007). Fossil samples were selected from a ca. $17 \mathrm{~m}$ long sediment sequence, core Co1215, spanning the last interglacial-glacial period (ca. 91.0 cal ka BP, DAMASCHKE et al. 2013). Core Co1215 was recovered in the autumn 2011, at a coring location in the central northern part of the lake basin during a field campaign of the projects Scientific Collaboration on Past Speciation Conditions in Lake Ohrid (SCOPSCO, http:// www.ohrid-drilling.org/) and "The Collaborative Research Centre (CRC) 806: Our Way to Europe - Culture-Environment Interaction and Human Mobility in the Late Quaternary" B2 (http://www.sfb806.uni-koeln.de/index.php/project/ cluster-b/b2). A diatom based palaeoenvironmental reconstruction of Lake Prespa has been published (CVETKOSKA et al. 2014c, d).

All samples analyzed during this study have been deposited in the Macedonian National Diatom Collection (MKNDC), at the Institute of Biology in Skopje, Macedonia.

Slides. Samples used during the study were treated either with potassium permanganate, $\mathrm{KMnO}_{4}$ and $30 \%$ hydrochloric acid, $\mathrm{HCl}$ (modern samples), or with $10 \%$ and $30 \% \mathrm{HCl}$ and $30 \%$ hydrogen peroxide $\mathrm{H}_{2} \mathrm{O}_{2}$ (fossil samples) to oxidize organics and to remove the carbonates. The cleaning procedure is presented in more detail in CVETKOSKA et al. (2012). Naphrax ${ }^{\mathbb{B}}$ was used as a mounting medium for preparation of the permanent diatom slides; the slides were further observed using oil immersion at x1500 magnification with a Nikon Eclipse 80i microscope. Light microscope (LM) imaging was performed with a Nikon Coolpix P6000 camera.
Aliquots of cleaned material, dried onto aluminum stubs and coated with gold-palladium (Polaron SC7640 sputter coater, Quorum Technologies, Ashford, UK) were used for Scanning electron microscope (SEM) analyses. SEM micrograph images were taken with an FEI Quanta FEG 200 SEM (FEI Munich, Gräfelfing, Germany), using accelerating voltages of $10 \mathrm{kV}$, at the Alfred Wegener Institute in Bremerhaven, Germany.

Holotype slides were deposited in the Macedonian National Diatom Collection (MKNDC) at the Institute of Biology in Skopje, Macedonia. Isotype slides were deposited in the Friedrich Hustedt Diatom Study Centre (BRM) in Bremerhaven, Germany and in the National Herbarium of Canada (CANA) at the Canadian Museum of Nature in Ottawa, Canada.

\section{ObServations AND discussion}

\section{Surirella prespanensis CvetKoska, Levkov et HA-} MILTON sp. nov. (Figs 1-20)

Valves isopolar, elliptic-lanceolate with acute apices. Valve length 70-155 $\mu \mathrm{m}$, width 37-72 $\mu \mathrm{m}$. Valve face undulate in apical direction extending from valve margin to median area, parallel in center, strongly radial towards valve apices (Figs 1-7). Each undulation ridge aligned with an alar canal with depressions between connected to fenestrae. Alar canals narrower than fenestrae, 15-20 in $100 \mu \mathrm{m}$. Striae fine, not clearly discernible in LM. In SEM, striae uniseriate on valve face, biseriate towards valve margin and on valve mantle (Fig. 10); stria density $23-25$ in $10 \mu \mathrm{m}$. Externally, striae open as simple round pores, covered with small silica granules in well-preserved specimens (Figs 12, 14). Internally, areolae round and rimmed (Figs 13, 18-20). Median area linear-lanceolate to narrow rectangular, and terminating prior valve apices, with fine striation sometimes not visible in LM. In SEM, median area forms an oblong raised ridge, covered with conic spines. Externally, conic spines and tubes present on undulations, together with groups of 2-3 somewhat longer conic spines on both, mantle and valve face sides of alar canals (Figs 8, 9, 11, 12, 14). Wing projection vertical, separated from valve face. Marginal keel with 4-5 parallel silicate grooves extending along both sides of raphe (Figs 11-14). Externally, raphe fissures deflected towards mantle (Figs 13, 14, 17, 20); internally, raphe fissures with simple ends on one pole and continuous at opposite pole. Fenestrae rectangular, occluded with 5-10 fenestral bars (Figs 8, 11, 17). Internally, alar canals cylindrical, alar openings simple elliptical portulae; internal valve margin with fine areolae in depressed rows, not rimmed (Figs 15, 16, 19).

Holotype: Here designated as circled specimen on slide MKNDC 005407/A, Holotype Fig. 2.

Isotypes: Slides: BRM ZU10/16, CANA 108583.

Type material: Lake Prespa, sediment, core Co1215 $\left(40^{\circ} 57^{\prime} 50^{\prime \prime} \mathrm{N}, 20^{\circ} 58^{\prime} 41^{\prime \prime} \mathrm{E}\right)$, collection date: Octo- 
ber 2009 (Accession No. MKNDC 005407). Slide MKNDC 005407/A, core depth $152 \mathrm{~cm}, 8.4 \mathrm{cal} \mathrm{ka} \mathrm{BP.}$ Type locality: Lake Prespa.

Etymology: The specific epithet (prespanensis) refers to the type locality, Lake Prespa.

Distribution: This species has been observed in the contemporary and fossil diatom flora of Lake Prespa.

Taxonomic notes: Surirella prespanensis resembles Surirella rotunda JuRILJ (1948, fig. 5; CVETKOSKA et al. 2015, figs 16-19) in valve size $(\mathrm{L}=90-120 \mu \mathrm{m}, \mathrm{W}=$ $65-70 \mu \mathrm{m}$ in $S$. rotunda vs. $\mathrm{L}=70-155 \mu \mathrm{m}, \mathrm{W}=37-72$ $\mu \mathrm{m}$ in $S$. prespanensis) and number of alar canals (1418 in $100 \mu \mathrm{m}$ in $S$. rotunda vs. $15-20$ in $100 \mu \mathrm{m}$ in $S$. prespanensis). However, comparisons with the original description and illustration and previous observations of $S$. rotunda (CVETKOSKA et al. 2014b, figs 16-19) reveal that both species possess distinct morphological characters which separate them as different taxa. These characters are the valve shape (almost circular with projected apices in $S$. rotunda vs. elliptic-lanceolate in $S$. prespanensis), with associated differences in the degree of radiation of the valve surface undulations and striae. In addition the shape of the median area (lanceolate in $S$. rotunda vs. linear-lanceolate to oblong in $S$. prespanensis) helps distinguish the taxa.

Surirella prespanensis is also similar to $S$. turgida W.SмIтн (1853, fig. 9: 60), however, it is distinguished by its larger valves and the isopolar valve morphology. Surirella turgida sensu KRAMmer \& LANGE-Bertalot (1988, figs 152: 1, 1A) and S. turgida sensu Hartley et al. (1996, fig. 280: 6) are also easily differentiated from $S$. prespanensis by the smaller valve length $(\mathrm{L}=58-80 \mu \mathrm{m}$ in $S$. turgida).

Surirella prespanensis is comparable with $S$. bifrons EHRENBERG (1843, figs 3/5: 5; 4/3: 1). EHRENBERG (op.cit.) presented two line drawings of Surirella bifrons; from different localities, Puente de Dios, Mexico (fig. 3/5: 5) and Newfoundland (fig. 4/3: 1), but both of them illustrate only the valve shape, without any information about the valve size. The drawing from Puente de Dios presents a slightly heteropolar valve with rhombic-lanceolate shape, while the Newfoundland valve is lanceolate in shape and probably isopolar. However, no additional characters can be noted in Ehrenberg's drawings. We have examined Ehrenberg's type material from Newfoundland and to date have not found intact valves for comparison. Due to this, the taxonomic concept of S. bifrons remains uncertain even today and different authors present various morphologies as $S$. bifrons. Additional confusion was created when HustedT (1911) changed the taxonomic position of S. bifrons to Surirella biseriata var. bifrons (EHRENBERG) HuSTEDT, based on differences in the valve shape; linear in $S$. biseriata and with convex margins in S. biseriata var. bifrons. The two line drawings illustrate $S$. biseriata var. bifrons as a taxon with linear-lanceolate shape, more or less projected apices and lanceolate median area (Husted in SCHMIDT 1874 1959, fig. 283: 3, 4). Further on, Cleve-Euler (1952, fig. 1528: f) followed the concept of MAYER (1918) for Surirella biseriata var. bifrons and provided the following description: "Valves short, rhombic-elliptic with rounded ends, median area lanceolate, the number of undulations is $12-17, \mathrm{~L}=80-140 \mu \mathrm{m}, \mathrm{W}=35-65$ $\mu \mathrm{m} . "$ Surirella bifrons sensu KRAMMER \& LANGE-BerTALOT (1997, figs 145: 2-4; 146: 1-4; 147: 1-5) represents a heterogeneous group of species. A number of species share the similar valve outline, but there is no detailed SEM examination of these taxa. S. bifrons sensu LeVKOv et al. (2007, fig. 204: 1-6) was identified in Lake Prespa modern samples during this study and can be clearly distinguished from $S$. prespanensis by its lanceolate valve shape, the presence of characteristic circular depression in the lanceolate median area, the smaller valve size $(\mathrm{L}=45-70 \mu \mathrm{m}, \mathrm{W}=20-27 \mu \mathrm{m})$ and higher number of alar canals (25-30 in $100 \mu \mathrm{m})$.

Thus, Surirella prespanensis represents a distinct taxon which can be separated from other similar taxa by its valve shape (linear lanceolate with acute, not protracted apices), the linear-lanceolate to oblong shape of the median area, the parallel alignment of the undulations in the central area, the number of alar canals $(15-20$ in $100 \mu \mathrm{m})$ and the presence of parallel silica grooves along the raphe.

\section{Surirella hinziae Cvetkoska, Levkov et Hamilton sp. nov. (Figs 21-32)}

Description: Valves isopolar about apical axis, lanceolate to narrow lanceolate with acute apices. Valve length 150-330 $\mu \mathrm{m}$, width 40-52 $\mu \mathrm{m}$. Valve face undulate in apical direction from valve margin to median area, parallel at center to radial on valve apices (Figs 21-26). Each undulation ridge aligned with alar canal and depressions between connected to fenestrae. Alar canals 12-20 in $100 \mu \mathrm{m}$. Striae fine, not clearly discernible in LM. In SEM, striae uniseriate on valve face, sometimes biseriate on valve mantle (Figs 30-32); stria density $32-34$ in $10 \mu \mathrm{m}$. Internally, striae present on entire valve face, continuing into space between alar canals (Figs 30, 32). Areolae externally open as small fissures or as simple elliptical pores (Figs 31, 32), internally areolae rimmed (Figs 30, 32). In LM, median area narrow, lanceolate. In SEM, externally median area an undulate, lanceolate raised ridge (Fig. 27). Internally, median area a narrow, deep lanceolate depression (Fig. 28) terminating before valve apices. Wing projection vertical, close to valve face. Marginal keel broadly rounded, with no pores or other surface features (Figs 27-29). Externally, raphe fissures deflected, terminating on valve mantle (Figs 31, 32). Internally, raphe fissures continuous at one end (Fig. 30) and discontinuous at opposite apex, ending in helictoglossa-like processes (Fig. 32). Internally, robust, cylindrical alar canals bridge the raphe canal (Figs 30, 32), alar openings horizontally elongated, elliptical portulae (Figs 
30, 32). Fenestrae openings round to elliptical, fenestral bars fine.

Holotype: Here designated as circled specimen on slide MKNDC 001118/A, Holotype Fig. 23.

Isotypes: Slides: BRM ZU10/17, CANA 108584.

Type material: Lake Prespa, sediment, core Co1215 $\left(40^{\circ} 57^{\prime} 50^{\prime \prime} \mathrm{N}, 20^{\circ} 58^{\prime} 41^{\prime \prime} \mathrm{E}\right)$, collection date: October 2009 (Accession No. MKNDC 005401). Slide MKNDC 005401/A, core depth $104 \mathrm{~cm}$, ca. $5.0 \mathrm{cal} \mathrm{ka}$ BP.

Type locality: Lake Prespa.

Etymology: This species is named in honor of Mrs. Friedel Hinz, Alfred Wegener Institute, Helmholtz Centre for Polar and Marine Research, Bremerhaven, Germany, for her great contribution to the curation of the Hustedt Collection and associated diatom taxonomy.

Distribution: This species has been observed solely in the fossil diatom flora of Lake Prespa.

Taxonomic notes: Surirella hinziae resembles $S$. biseriata sensu KRAMER \& LANGE-BERTALOT (1997, fig. 141: $1-3)$ in the valve size. $S$. hinziae can be distinguished from $S$. biseriata by its isopolar lanceolate to linearlanceolate valves with acute apices, compared to the slightly heteropolar valves with the acute or rounded ends of $S$. biseriata sensu KRAMER \& LANGE-BERTALOT. Nevertheless, the taxonomic concept of $S$. biseriata BRÉBISSON (IN BRÉBISSON \& Godey 1835: fig. 7) is rather unclear and different authors present different morphologies of this taxon. In the original protologue, BRÉBISSON (op.cit.) describes $S$. biseriata as a species with convex, oval frustules with two longitudinal series of striae, covered with granules, and provides a single line drawing illustrating a slightly heteropolar oval-shaped valve. Later, taxonomic confusion was created by a number of descriptions of different varieties and forms of $S$. biseriata; ultimately many taxa with different morphologies were included in this species complex. Surirella biseriata sensu KRAMMER \& LANGE-BERTALOT (1997, figs 141: 1-3; 142: 1-5; 143: 1-9; 144: 1-3) clearly represents a heterogeneous group. In the figure explanation Krammer \& LANGe-Bertalot (1997, figs 142: 3-5) state: "Lectotypus in Coll. Van Heruck Antwerpen V-30-C2", but their attempt for lectotypification is invalid. Surirella hinziae very likely represents a separate taxon which can be distinguished from $S$. biseriata sensu BRÉBISSON, S. biseriata sensu KRAMMER \& LANGe-Bertalot (1997: 142: 3-5), and from other similar taxa by its valve shape (isopolar, narrow lanceolate), valve size $(\mathrm{L}=150-330 \mu \mathrm{m}, \mathrm{W}=40-52 \mu \mathrm{m})$ and the narrow, lanceolate and undulated median area.

Surirella hinziae resembles $S$. biseriata var. elongata PANTOCSEK (1902, fig. 12: 293) in its valve shape and size. PANTOCSEK described this taxon from Lake Balaton and provided a single line drawing of the species. His description translates as: "valves elonga- ted lanceolate with slightly protracted, obtuse poles, L $=291-292 \mu \mathrm{m}, \mathrm{W}=40-42 \mu \mathrm{m}$, covered with irregularly arranged punctae". Cleve-Euler (1952: 107, fig. 1529) changed the taxonomic position of PANTOCSEK's taxon to Surirella elongata (PANTOCSEK) CLEVE-Euler. However, this change was invalid, because Surirella elongata (PANTOCSEK) CLeve-Euler is a later homonym of Surirella elongata BréBISSON ex PERAgallo \& Peragallo (1899: 259, fig. 68: 1). Surirella hinziae can be differentiated from $S$. biseriata var. elongata by the shape of the median ridge (narrow, linear in S. biseriata var. elongata vs. undulated lanceolate in S. hinziae) and by the absence of conic spines and tubes on the undulations.

Surirella lineopunctata JuRILJ (1948, fig. 6: a, b) is Lake Ohird's endemic species with lanceolate valves of comparable size $(\mathrm{L}=120-300 \mu \mathrm{m}, \mathrm{W}=30-50 \mu \mathrm{m})$ to $S$. hinziae, but with a distinctly different shape of the valve apices (cuneate to subrostrate in $S$. lineopuncta$t a)$, higher density of the alar canals (20-25 in $100 \mu \mathrm{m})$ and narrow linear shape of the median ridge.

Surirella fuellebornii MüLlER (1903, p. 30) was originally described as a planktonic species from Lake Malombae, Africa. CocQuYT \& JAHN (2007, fig. 2: a-e) designated the lectotype and extended the morphological description of $S$. fuellebornii. Although similar in valve outline and length $(\mathrm{L}=173-373 \mu \mathrm{m})$, this species with wide distribution in many African lakes has broader valves $(\mathrm{W}=53-67 \mu \mathrm{m})$ than $S$. hinziae, subrostrate poles, lower density of the alar canals (15-18 in $100 \mu \mathrm{m}$ in $S$. fuellerbornii), strong, finely punctuate radial to divergent undulations, and sometimes a constriction in the middle of the valve as morphological variation.

Surirella archibaldii Metzeltin \& LANGe-BerTALOT (2002, figs 87: 7, 8; 88: 1-3; 89: 1-5; 90: 1-3), described from the river Namorona, Madagascar, belongs to the "Robustae" section and shares similar, isopolar linear valve outline with $S$. hinziae. However, S. archibaldii has a variable valve outline; from elliptic in the smallest, to linear-elliptic and linear in the largest specimens. In addition, both species differ in valve size, especially the width $(\mathrm{L}=100-180 \mu \mathrm{m}, \mathrm{W}$ $=14-28 \mu \mathrm{m}$ in $S$. archibaldii vs. $\mathrm{L}=50-330 \mu \mathrm{m}, \mathrm{W}=$ $40-52 \mu \mathrm{m}$ in $S$. hinziae), valve length/width ratio ( ca. 6.5 in $S$. archibaldii and ca. 4 in $S$. hinziae), number of alar canals (25-30 in $100 \mu \mathrm{m}$ in $S$. archibaldii vs. $12-$ 20 in $100 \mu \mathrm{m}$ in $S$. hinziae), stria density (15 in $10 \mu \mathrm{m}$ in $S$. archibaldii vs. $32-34$ in $10 \mu \mathrm{m}$ in $S$. hinziae), shape of the median ridge (hyaline and wide-lanceolate in $S$. archibaldii vs. narrow lanceolate and undulated in S. hinziae) and the presence of spines in S. archibaldii.

In conclusion, $S$. hinziae represents a distinct taxon, discernible from other similar taxa by the isopolar narrow lanceolate valves, valve size $(\mathrm{L}=150-330$ $\mu \mathrm{m}, \mathrm{W}=40-52 \mu \mathrm{m})$, undulated lanceolate median ridge and the absence of conical spines and/or tubes. In addition, the distinct presence of the internal helicto- 

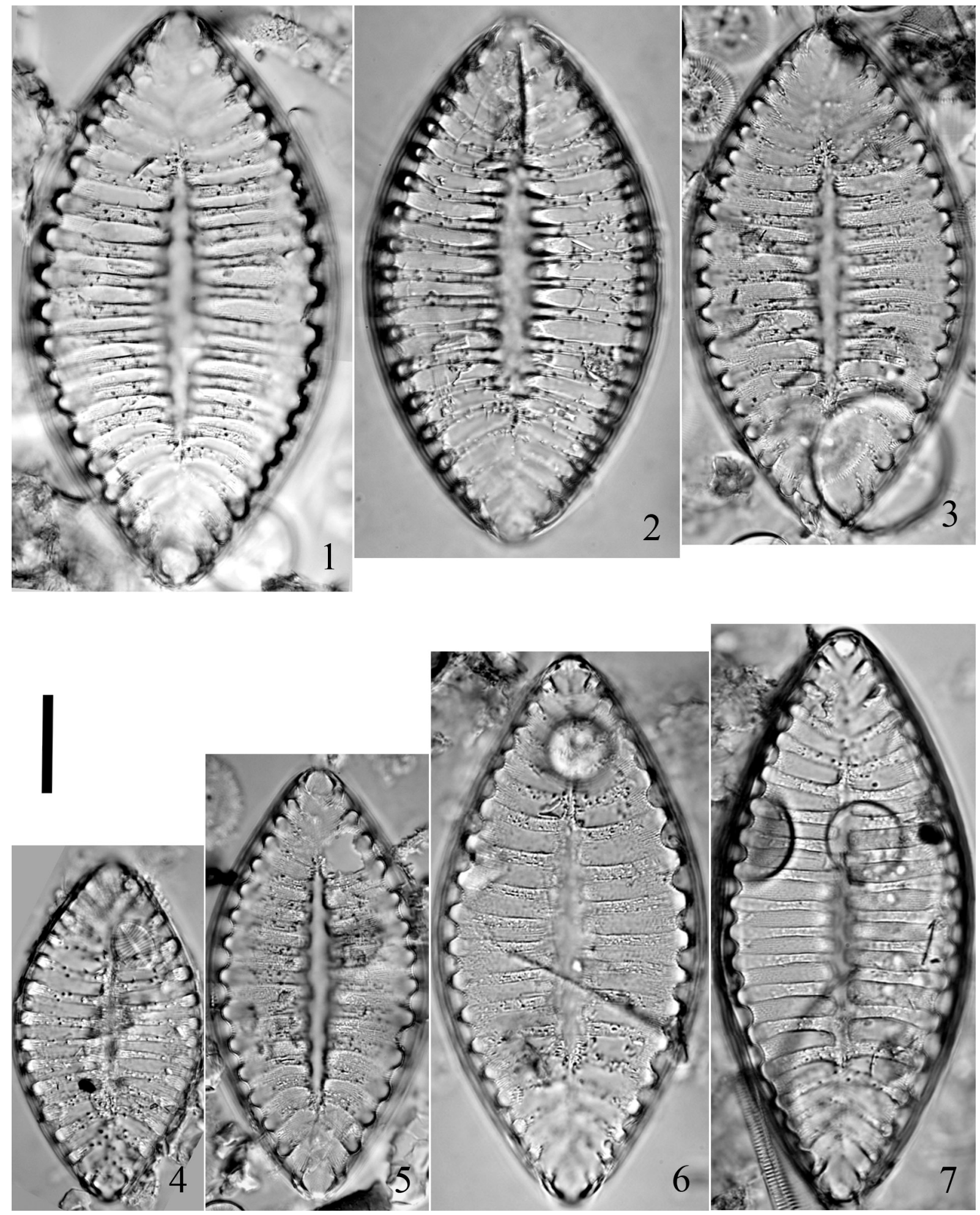

Figs 1-7. Surirella prespanensis sp. nov., LM valve views, (2) holotype (Lake Prespa core Co1215, $152 \mathrm{~cm}$ core depth, ca. $8.4 \mathrm{cal}$ ka BP). Scale bar $20 \mu \mathrm{m}$ 

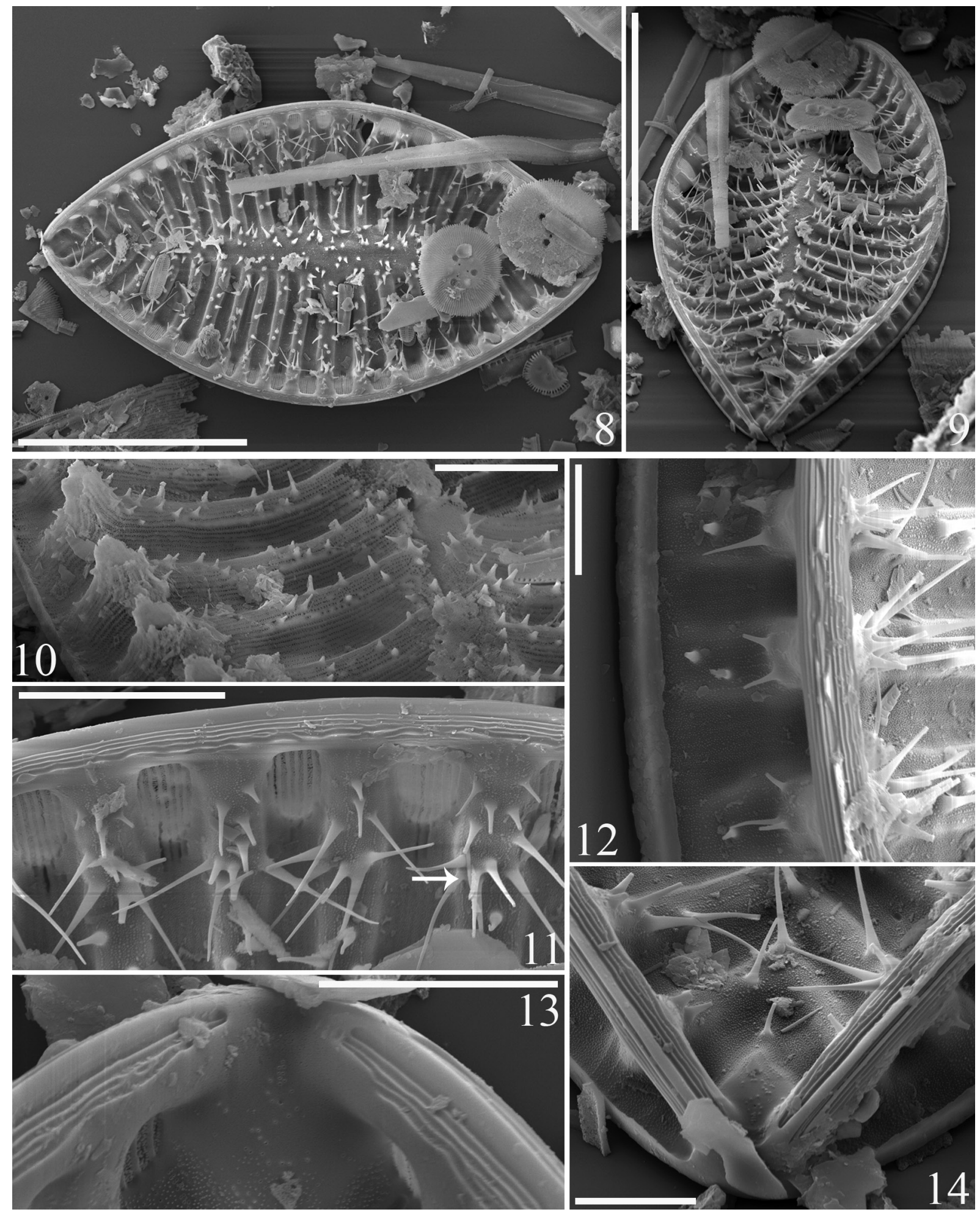

Figs 8-14. Surirella prespanensis sp. nov., SEM external valve views showing: (8-10) the median area covered with conic spines; (11-14) the marginal keel with $4-5$ silicate grooves; $(14)$ the deflected raphe fissures; $(8,11)$ the fenestrae occluded by $5-10$ fenestral bars and $(11$, arrow) the groups of longer conical spines on the alar canals. Scale bars $50 \mu \mathrm{m}(8,9), 10 \mu \mathrm{m}(10,11), 5 \mu \mathrm{m}(12-14) .(8,9,11-14)$ Lake Prespa sediment sequence Co1215, $168 \mathrm{~cm}$ core depth, ca. $9.8 \mathrm{cal} \mathrm{ka} \mathrm{BP.} \mathrm{(10)} \mathrm{Lake} \mathrm{Prespa} \mathrm{core} \mathrm{Co1215,} 104 \mathrm{~cm}$ core depth, ca. $5.1 \mathrm{cal}$ ka BP. 


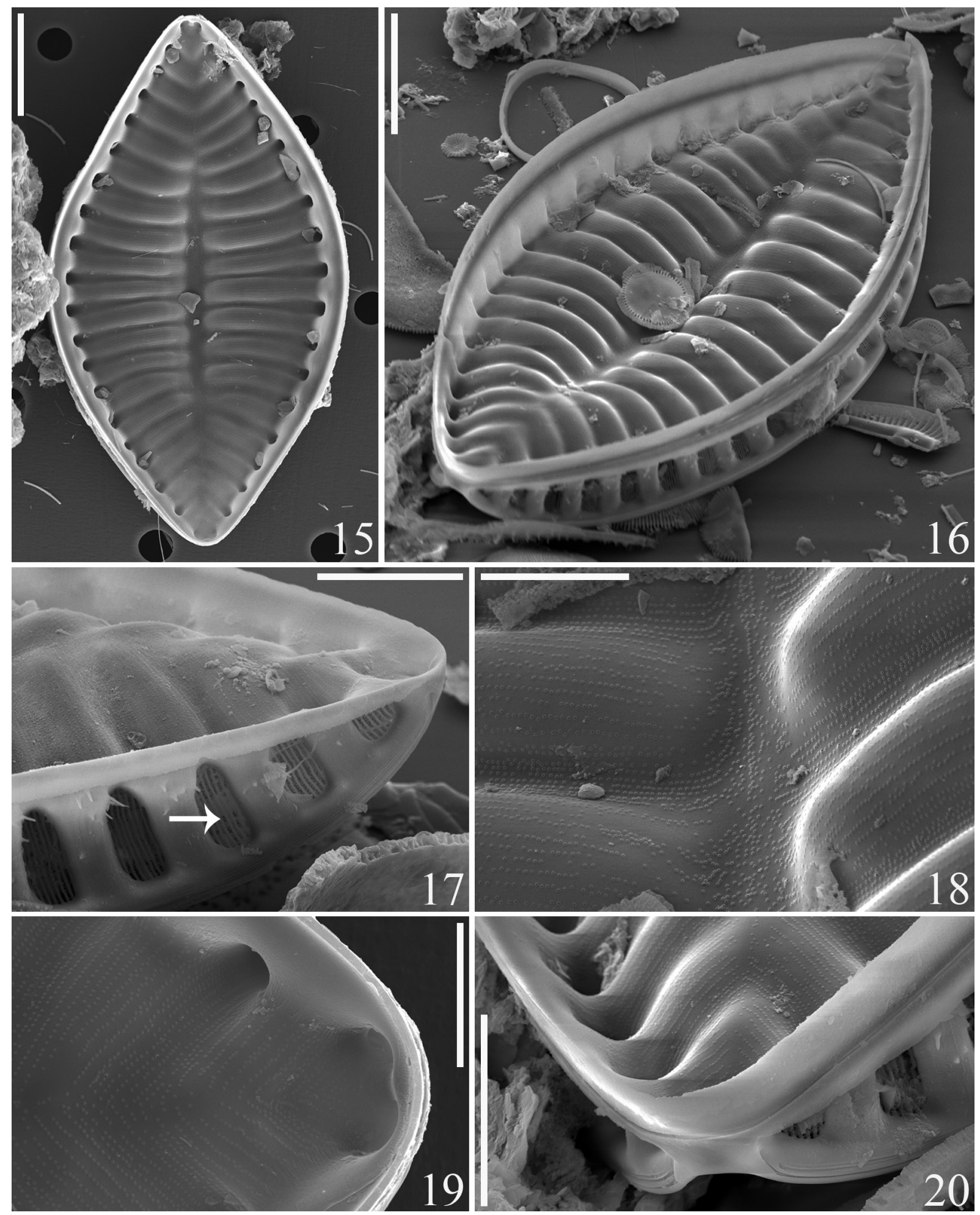

Figs 15-20. Surirella prespanensis sp. nov., SEM internal valve views showing: $(18-20)$ the rimmed pores; $(15,16,19,20)$ the cylindrical alar canals with simple elliptical alar openings; (17) detail of the valve apical part showing the valve mantle and the rectangular fenestrae, occluded by $5-10$ fenestral bars (arrow). Scale bars $20 \mu \mathrm{m}(15,16), 10 \mu \mathrm{m}(17,20), 5 \mu \mathrm{m}(18,19)$. (15, 19) Lake Prespa core Co1215, $176 \mathrm{~cm}$ core depth, ca. $10.1 \mathrm{cal}$ ka BP. $(16-18,20)$ Lake Prespa core Co1215, $104 \mathrm{~cm}$ core depth, ca. $5.1 \mathrm{cal}$ ka BP. 


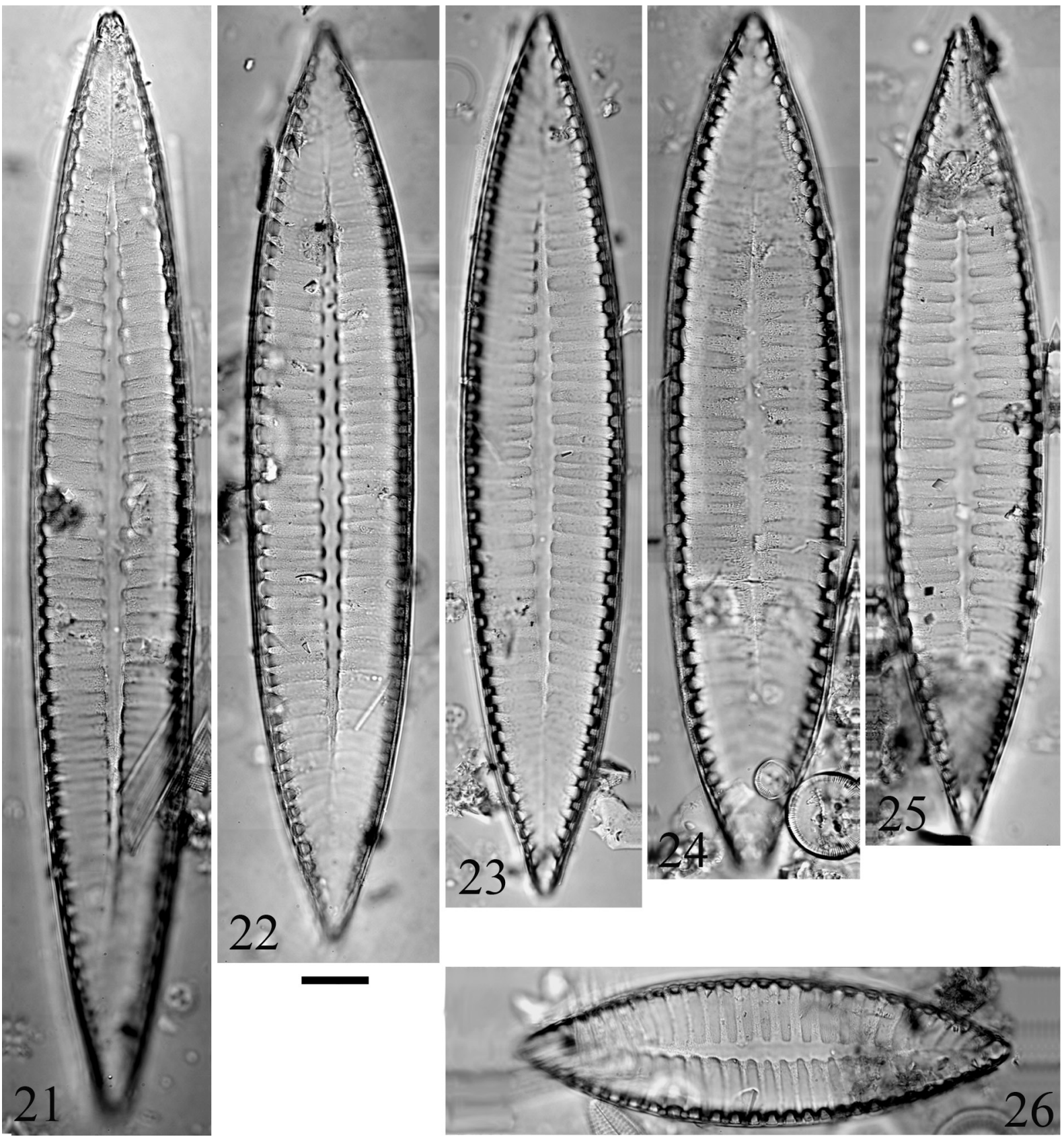

Figs 21-26. Surirella hinziae sp. nov., LM valve views, (23) holotype (Lake Prespa core Co1215, $104 \mathrm{~cm}$ core depth, ca. 5.0 cal ka BP). Scale bar $20 \mu \mathrm{m}$.

glossa-like processes at the raphe terminations, can be considered as a differentiating character, so far reported only in a few species within this genus, like Surirella robusta, S. splendida (EHRENBERG) KÜTZING (1844, fig. 7:9) and S. rumrichorum MetZeltin \& LANGe-BerTALOT (1998, figs 219: 7; 216: 2-3).

ACKnowledgements

This study was partly funded by the Alexander von Humboldt Foundation as part of the project "Reconstruction of past environmental variations in ancient Lake Ohrid, a diatom inferred perspective". We thank our colleagues from the Institute of Geology and Mineralogy and the Seminar of Geography and Education (University of Cologne, Germany) for providing the core Co1215 sediment samp- les and data. We are grateful to Dr. Bánk Bestzeri and Mrs. Friedel Hinz, Alfred Wegener Institute for Polar and Marine Research, Bremerhaven, Germany for their assistance during our research stay at the Hustedt's Diatom Centre. Many thanks to Mrs. Danijela Mitić Kopanja, Institute of Biology, Faculty of Natural Sciences, Skopje, Macedonia for technical assistance. Financial support to A.C. was given by the Canadian Museum of Nature under the Center for Species Discovery and Change.

\section{REFERENCES}

Albrecht, C. \& Wilke, T. (2008): Ancient Lake Ohrid: biodiversity and evolution. - Hydrobiologia 615: 103140. doi: 10.1007/s10750-008-9558-y. 

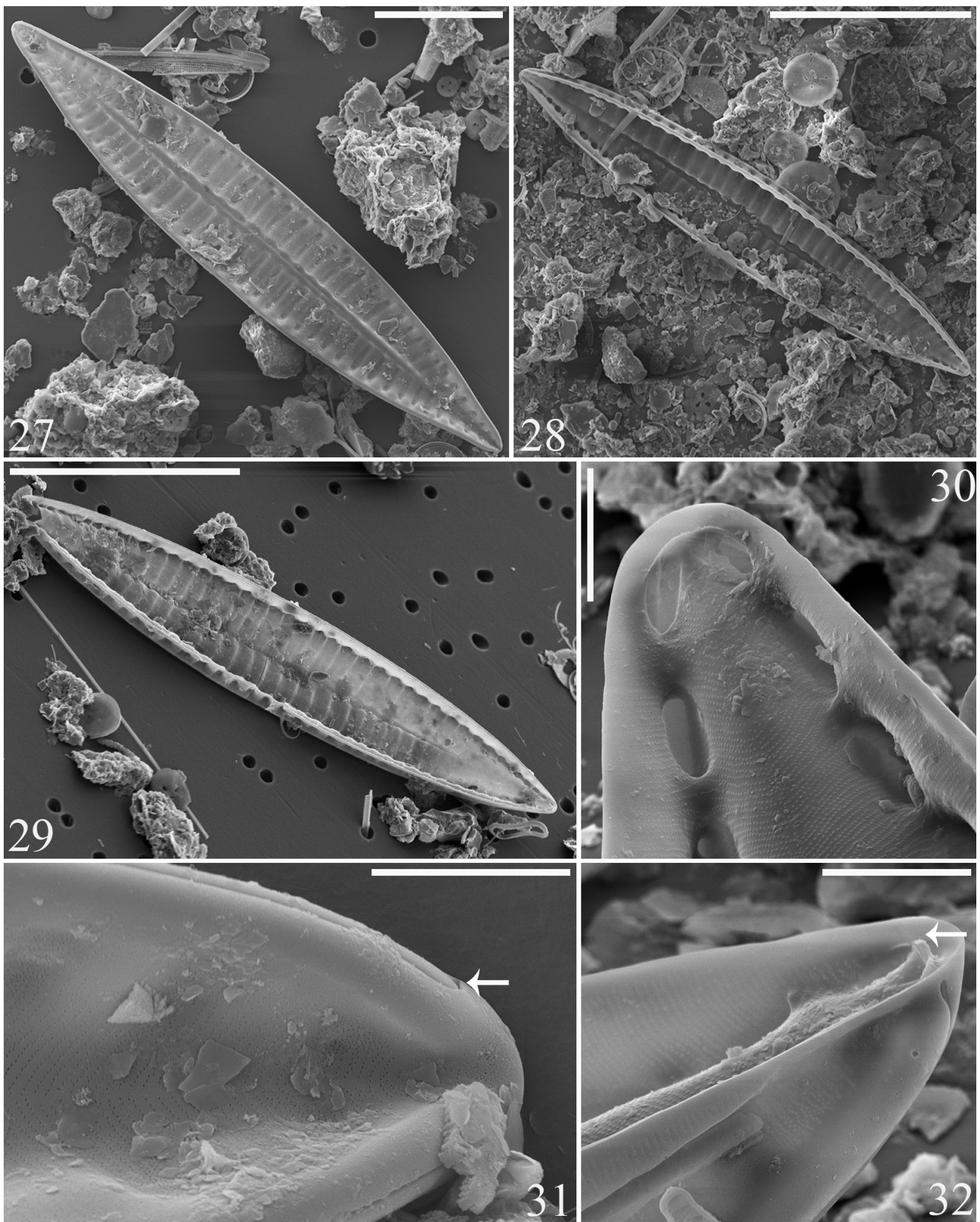

Figs 27-32. Surirella hinziae sp. nov., SEM: (27,31) external valve views showing the apically undulated lanceolate ridge, the broadly rounded marginal keel, the areolae openings and the deflected raphe fissures (31, arrow); (28-30) internal valve views showing, (30) the rimmed areolae, (28) the depressed median ridge and (30) the elongated elliptical alar openings; (32) detail of the valve apical part showing the valve mantle and the helictoglossa-like processes at valve terminations (arrow). Scale bars $100 \mu \mathrm{m}(28,29), 50 \mu \mathrm{m}(27), 5 \mu \mathrm{m}(30-32)$. (29, 30, 32) Lake Prespa core Co1215, $176 \mathrm{~cm}$ core depth, ca. $10.1 \mathrm{cal} \mathrm{ka} \mathrm{BP.} \mathrm{(31)} \mathrm{Lake} \mathrm{Prespa} \mathrm{core} \mathrm{Co1215,} 184 \mathrm{~cm}$ core depth, ca. $10.5 \mathrm{cal}$ ka BP. 
Bramburger, A.J.; Hamilton, P.B.; Hehanussa, P.E. \& HaffNER, D.G. (2008): Processes regulating the community composition and relative abundance of taxa in the diatom communities of the Malili Lakes, Sulawesi Island, Indonesia. - Hydrobiologia 615: 215-224. doi:10.1007/s10750-008-9562-2.

Brébisson, L.A. DE \& Godey, L.L. (1835): Algues des environs de Falaise, décrites et dessinées Mémoires de la Société Académique des Sciences, Arts et BellesLettres de Falaise. - Imprimerie de Brée L'Aîné, Falaise 1-66, 256-269, 8 pls.

Fourtanier, E. \& Kociolek, J.P. (2011): Catalogue of Diatom Names, California Academy of Sciences, Online Version updated 19 Sep 2011. Available online at http://research.calacademy.org/research/diatoms/ names/index.asp.

Cleve-Euler, A. (1952): Die Diatomeen von Schweden und Finnland. Part V. (Schluss.). - Kongliga Svenska Vetenskaps-Akademiens Handligar, ser. 4, 3: 1-153, figs 1318-1583, pl. 7.

COCQUYT, C. \& JAHN, R. (2005): Rare Surirella taxa (Bacillariophyta) from East Africa described by Otto Müller: typifications, recombinations, new names, annotations and distributions. - Willdenowia 35: 359-371. http://www.jstor.org/stable/3997670.

Cocquyt, C. \& JAHN, R. (2007): Surirella nyassae O. Müller, S. malombae O. Müller, S. chepurnovii Cocquyt \& R. Jahn sp. nov. (Bacillariophyta) - Typification and variability of three closely related East African diatoms. - Nova Hedwigia 84: 529-548. doi: 10.1127/0029-5035/2007/0084-0529.

Cocquyt, C.; Kusber, W-H. \& JAHN, R. (2008): Otto Müller's Surirella taxa (Bacillariophyta) from East Africa, based on a historical collection kept at the Botanic Garden and Botanical Museum Berlin-Dahlem (B). - Afrika Focus 21: 65-75.

Cvetkoska, A.; Hamilton, P.B.; Ognjanova-Rumenova, N. \& Levkov, Z. (2014a): Observations of the genus Cyclotella (Kützing) Brébisson in ancient lakes Ohrid and Prespa and a description of two new species $C$. paraocellata sp. nov. and $C$. prespanensis sp. nov. - Nova Hedwigia 98: 313-340. doi: 10.1127/0029$5035 / 2014 / 0154$

Cvetkoska, A.; Levkov, Z. \& Hamilton, P.B. (2014b): Surirella subrotunda sp. nov. and Surirella parahelvetica sp. nov., two new diatom (Bacillariophyta) species from Lake Prespa, Macedonia. - Phytotaxa 156: 145-155. doi: 10.11646/phytotaxa.156.3.5.

Cvetkoska, A.; Levkov, Z.; Reed, J.M. \& Wagner, B. (2014c): Late glacial to Holocene climate change and human impact in the Mediterranean: the last ca. $17 \mathrm{ka}$ diatom record of Lake Prespa (Macedonia/ Albania/Greece). - Palaeogeography, Palaeoclimatology, Palaeoecology 406: 22-32. doi: 10.1016/j. palaeo.2014.04.010.

Cvetkoska, A.; Levkov, Z.; Reed, J.M.; Wagner, B.; Panagiotopoulos, K.; Leng, M. \& LaceY, J. (2015): Quaternary climate change and Heinrich events in the southern Balkans: Lake Prespa diatom palaeolimnology from the last interglacial to present. - Journal of Paleolimnology 53: 215-231. doi: 10.1007/s10933014-9821-3.

Cvetkoska, A.; Reed, J.M. \& Levkov, Z. (2012): Diatoms as indicators of environmental change in ancient Lake Ohrid during the last glacial-interglacial cycle (ca.
140 ka). - Diatom Monographs 15: 1-220.

DamaschKe, M.; Sulpizio, R.; Zanchetta, G.; Wagner, B.; BöHm, A.; NowaczyK, N.; Rethemeyer, J. \& Hilgers, A. (2013): Tephrostratigraphic studies on a sediment core from Lake Prespa in the Balkans. - Climate of the Past 9: 267-287. doi: 10.5194/cp-9-267-2013.

EhrenBerG, C.G. (1843): Verbreitung und Einflufs des mikroskopischen Lebens in Süd- und Nord Amerika. - Abhandlungen der Königlichen Akademie der Wissenschaften zu Berlin 1841: 291-445.

Fotт, B. (1933): Die Schwebeflora des Ohrid-Sees. - Bulletin de l'institut et du Jardin Botaniques de l'Universite de Beograd 2: 153-175.

Fотт, B. (1935): Phytoplanktonproduktion des Ohridsees. - Verhandlungen der Internationalen Vereinigung für Theoretsiche und Anfewandte Limnologie 7: 229-236.

Hartley, B.; Barber, H.G.; Carter, J.R. \& Sims, P.A. (1996): An Atlas of British Diatoms. - Biopress Limited, Bristol, 1-601.

Hustedt, F. (1911): Beiträge zur Algenflora von Bremen. IV. - Bacillariaceer aus der Wumme. Abhandlungen des Naturwissenschaftlichen Verein zu Bremen 20: 257-315, Tafs 2-3.

JurILJ, A. (1948): Nove dijatomeje- Surirellaceae - iz Ohridskog jezera i njihovo filogenetsko znacenje. Jugoslovenska Akademija, Zagreb. - Prirodnoslovnih Istrazivanja 24: 171-260.

JuRILJ, A. (1954): Flora i vegetacija dijatomeja Ohridskog jezera. Jugoslovenska Akademija, Zagreb. - Prirodnoslovnih Istrazivanja 26: 99-190.

JuRILJ, A. (1956a): Osobitosti mikroflore Ohridskog Jezen (The peculiarities of the microflora from Lake Ohrida in Yugoslavia). - Godisnjak Bioloskog Instituta $u$ Sarajevu (Annuaire de 1'Institut Biologique a Sarajevo) $1-2: 177-184$.

JuRILJ, A. (1956b): La phylogénése spécifique d'un groupe de diatomeés - Camplidiscoideae - et sa cause. Hydrobiologia 8: 1-15.

Karthick, B. (2009): Hemendrakumar Prithivraj Gandhi (1920 - 2008). - Diatom Research 24: 509-520. doi: 10.1080/0269249X.2009.9705820.

Karthick, B.; Hamilton, P.B. \& Kociolek, J.P. (2012): Taxonomy and biogeography of some Surirella Turpin (Bacillariophyceae) taxa from Peninsular India. Nova Hedwigia 141: 81-116.

Krammer, K. \& Lange-Bertalot, H. (1988): Bacillariophyceae. 2. Teil: Bacillariaceae, Epithemiaceae, Surirellaceae. - In: Ettr, H.; Gerloff, J.; Heynig, H. \& Mollenhauer, D. (eds): Süsswasserflora von Mitteleuropa 2/2. - 596 pp, Gustav Fischer Verlag, Stuttgart.

Krammer, K. \& Lange-Bertalot, H. (1997): Bacillariophyceae 2. Teil: Bacillariaceae, Epithemiaceae, Surirellaceae. - In: Ettl, H.; Gerloff, J.; Heynig, H.; Mollenhauer, D. (eds): Süßwasserflora von Mitteleuropa, 2/2. - 536 pp., Gustav Fischer Verlag, Stuttgart.

KüTZING, F.T. (1844): Die Kieselschaligen. Bacillarien oder Diatomeen. - Nordhausen: Förstemann, 1-152.

Levkov, Z. \& Williams, D.M. (2012): Checklist of diatoms (Bacillariophyta) from Lake Ohrid and Lake Prespa (Macedonia), and their watersheds. - Phytotaxa 45: $1-76$.

Levkov, Z.; Krstic, S.; Metzeltin, D. \& Nakov, T. (2007): 
Diatoms of Lakes Prespa and Ohrid (Macedonia). Iconographia Diatomologica 16: 1-613.

MaYer, A. (1918): Bacillariales der Umgegend von Ortenburg (Niederbayern). - Kryptogamische Forschungen herausgegeben von der Kryptogamenkommission der Bayerischen Botanischen Gesellschaft zur Erforschung der heimischen Flora 1: 122-129, pls. 3-4.

Metzeltin, D. \& Lange-Bertalot, H. (1998): Tropical diatoms of South America I: About 700 predominantly rarely known or new taxa representative of the neotropical flora. - In: LANGE-BERTALOT, H. (ed.): Iconographia Diatomologica. Annotated Diatom Micrographs. Vol. 5. Diversity-Taxonomy-Geobotany. - 695 pp., Koeltz Scientific Books. Königstein, Germany.

Metzeltin, D. \& Lange-Bertalot, H. (2002): Diatoms from the "Island Continent" Madagascar. - In: LANGEBertalot, H. (ed.): Iconographia Diatomologica. Annotated Diatom Micrographs. Vol. 11. TaxonomyBiogeography-Diversity. - 286 pp., A.R.G. Gantner Verlag K.G.

MüLLER, O. (1903): Bacillariaceen aus dem Nyassalande und einigen benachbarten Gebieten. - I. Botanische Jahrbücher 34: 9-38.

Ognjanova-Rumenova, N. \& Dumurdzhanov, N. (2008): Neogene diatom biostratigraphy and palaeoecology of the lacustrine sediments of Macedonia. - In: BoEv, B. \& Serafimovski, T. (ed.): Proceedings of the $1^{\text {st }}$ Geological Congress, Ohrid. - Geologica Macedonica 2: 5-20. (in Macedonian).

Ognjanova-Rumenova, N.. \& Crawford, R.M. (2012): Morphology and ultrastructure of the fossil freshwater diatom Aulacoseira temperei. - Diatom Research 27: 107-119. doi: 10.1080/0269249X.2012.696495.

Pantocsek, J. (1902): Kieselalgen oder Bacillarien des Balaton. Resultate der Wissenschaftlichen Erforschung des Balatonsees, herausgegeben von der BalatonseeCommission der Ung. Geographischen Gesellschaft. - Commissionsverlag von Ed. Hölzel. Wien. 2: 112 pp., 17 pls.
Peragallo, H. \& Peragallo, M. (1899): Diatomées Marines de France et des Districts Maritimes Voisins. - Atlas. - In : Tempere, J. (ed.) : Micrographe-Editeur, à Grez-sur-Loing (S.-et-M.). - pls. 49-72, Grez-surLoing, France.

RUCK, E.C. \& Kociolek, J.P. (2004): Preliminary phylogeny of the family Surirellaceae (Bacillariophyta). - Bibliotheca Diatomologica 50: 1-236.

Schmid, A. (1874-1959): Atlas der Diatomaceen-kunde. R. Reisland, Leipzig. [Pls. 1-212, 1874-1897, A. Schmidt ; 213-216, 1899, M. Schmidt; 217-232, 1899-1902, F. Fricke; 233-240, 1902, F. Fricke; 241-244, 1903, H. Heiden; 245-246, 1904, Otto Müller; 247-248, 1904, M. Schmidt \& F. Fricke; 249-252, 1904, F. Fricke; 253-256, 1905, F. Fricke; 257-264, 1905-1906, H. Heiden; 265, 267-268, 1906, F. Fricke; 266, 1906, M. Schmidt \& F. Fricke; 269-480, 1911-1959, F. Hustedt].

Sмiтh, W. (1853): Synopsis of British Diatomaceae. - John Van Voorst, London, 1: $89 \mathrm{pp}$

STANKović, S. (1960): The Balkan Lake Ohrid and its living world. - 357 pp., Monographie Biologicae 9, Uitgeverij Dr Junk, Den Haag.

TuRPIN, P.J.F. (1828): Observations sur le nouveau genre $\mathrm{Su}$ rirella. - Mémoires du Museum d'Histoire Naturelle 16: 361-368.

Veselá, J. \& Potapova, M. (2014): Surirella arctica comb. et stat. nov. (Bacillariophyta) - a rare arctic diatom. - Phytotaxa 166: 222-234. doi: 10.11646/phytotaxa.166.3.3.

Veselá, J.; Johansen, J.R. \& Potapova, M. (2013): Surirella terryi and S. cruciata: two rare diatoms from North America. - Diatom Research 28: 503-516. doi: 10.1080/0269249X.2013.853697.

(C) Czech Phycological Society (2015)

Received February 23, 2015

Accepted April 29, 2015 